\title{
Using an Improvised Abacus to Assist Samproso M/A Junior High School Level One Pupils to Overcome the Problem of Place Value Concept in Mathematics
}

\author{
Daniel Amoah* Med. , Kwame B. Bour ${ }^{1}$ Mphil. Samuel Boampong ${ }^{2}$ Med. Bright Arkoh ${ }^{3}$ Dip. \\ * Berekum College of Education, Berekum, Brong Ahafo Region Ghana-W/A \\ 1. Agona College of Education, Agona-Ashanti Region of Ghana- W/A \\ 2. St. Joseph's College of Education, Bechem-Brong Ahafo Region of Ghana W/A. \\ 3. Offinso College of Education, Offinso-Ashanti Region of Ghana W/A
}

\begin{abstract}
This study is an action research work done to help the JHS one (1) pupils of Samproso M/A Basic School in Off in so South Municipal Assembly to identify place value of $4-5$ digits in numerals. The study was undertaken in order to bring out the meaning of place value, the importance of teaching and learning materials (TLMs) in teaching and also the teaching and learning materials (TLMs) that could be used in teaching place value as a concept in mathematics. The study used an improvised abacus to help improve pupils' understanding of the concept of place value. Purposive as well as random sampling technique was selected and used as the study was limited to where the problem was identified and they all shared the same problem. In all, sixty-five (65) pupils comprising thirty-three (33) boys and thirty-two girls from the sample groups were used. Three research questions were formulated to guide the study. Pre-test, observation, interview questionnaire and post-test were the research instruments used to gather reliable data for the study. Pupils were also found to have developed favourable attitude towards mathematics. Recommendations were made with regards to teachers and pupils' attitude in the teaching of mathematics at the basic school level.
\end{abstract}

\section{Introduction}

Many Ghanaian students today are faced with difficulties in dealing with mathematical problems in school, especially at the basic level. During the recent teaching practice (school attachment programme), the researchers noticed that, pupils in class have the problem of place value and as a results perform poorly in class exercises and assignments. In view of this, the researchers adopted the use of abacus to help pupils overcome their place value difficulties.

\section{Background of the Study}

Mathematics as a discipline is an ideal aspect of our daily activities. It is the "life-blood of development. As a result of mathematics, there is a great gap between the developing and developed countries. This gap is as results of the great premium developed countries placed on mathematics than developing counties which do not regard mathematics as an instrument for development. Mathematics all over the world is well accepted as a subject or course that every child throughout the world should study in school. This is because of its application in our work place, school and in our daily activities. Many children in our junior high schools are finding it difficult to understand the fundamental concepts and skills to solve mathematical problems. Many pupils in our senior and junior high schools pass their examinations without acquiring the prerequisite understanding of most fundamental concept and principles in finding solutions. However, the poor performance in mathematics by most Ghanaian pupils in our schools today come to light in 1992 when a criterion reference test (CRT) was conducted for pupils in basic schools throughout the communities in country that shows that, the competence was very low.

Again, most of the pupils pass their mathematics examinations without acquiring proper pre-requisite understanding of the most fundamental concepts, the pupils cannot be blamed alone since lack of adequate 
teaching and learning materials of which both the teachers and the learners need to promote efficient and effective teaching and learning in the classroom and outside the classroom and even homes are nonexistence. The concept of place value is essential to help pupils' performances change for the better. This ability of pupils to identify the position of a digit in a numeral is in dispensable fact as far as mathematics is concerned. In effect to this it calls for the attention of many educationists (Anamuah-Mensah, 1996) indeed the performance of pupils in mathematics at the senior and junior high levels have become great concern to all beneficiaries and stakeholders of education.

Asiedu (1998), the downward trend of performance in mathematics in recent years is a source of worry to not only parents but to all stakeholders of education and beneficiaries in the country. It was observed that whenever teaching the topic "place value" without using any teaching and learning materials (TLMs), and evaluation of the lesson was conducted, pupils were not able to answer the test items that were given to them well. Critical observation revealed that, appropriate TLMs which should be used to enhance the understanding and also to sustain the interest of the pupils in the lesson were not used by the pupils. This makes mathematics which is supposed to be the most interesting subject to pupils, become boring and this makes pupils dislike it. Place value, in mathematics is a set of numbers greater than nine or the position of a digit in numerals. A sound knowledge of place is essential for addition, subtraction, multiplication and division. It is an applicable concept in every level of education to enhance in-depth understanding of mathematics. Children need it grasp the concept for them to demonstrate efficiency in any field of their endeavor.

In view of this, the researchers decided to use appropriate TLM called "ABACUS" as an intervention to assist or aid pupils to practically teach and enhance their understanding of the topic "place value" in mathematics to improve the performance of the class.

\section{Purpose of the Study}

The main purpose of the study to come out with an improvised instrument (abacus) which could be used to teach pupils the concept of place value for the pupils of Samproso M/A JHS one to be able to work with whole numbers greater than 9, they must first understand the concept of digits of numbers in numerals place value. The understanding of base ten (10) concept cannot be achieved without the pupils of Samproso M/A JHS one (1) first knowing what place value is. Also, since the researcher is using an improvised abacus to teach the place value, the pupils must know what abacus consist of.

\section{Research Questions}

To be able to investigate and come out with the appropriate solution, the researcher has several questions or problems in mind of which all of them cannot be addressed in this particular study alone. Among these questions in mind is what the researchers have attempted to address:

1. Are the teachers using learner-centered activity method in teaching?

2. How possible will the use of abacus in teaching mathematics sustain the interest of the pupils of Samproso M/A JHS one (1)?

3. What are the roles parents play in education?

4. What are the educational and commitment level of the teachers?

\section{Significance of the Study}

Children learn effectively when they are given the chance to play and manipulate teaching and learning materials. They learn rapidly when they are placed at the center of the teaching and learning process. It is in the light of this that the researcher used the learner centered activities to assist the pupils of Samproso M/A JHS to overcome the predicament in place value. Since place value is an important element in mathematics, there is the need for teachers to use the best approach to help the pupils understand the concept. On the other hand, this project is in position to guide pupils to understand the concept of place value and inform teachers and other stakeholders on the need to use relevant teaching and learning materials in teaching place value. The study will encourage pupils who are studying mathematics at Samproso M/A JHS one (1) to demystify mathematics. The findings will be beneficial to both teachers teaching the concept of place value and curriculum developers when planning the mathematics curriculum. 


\section{Importance of Mathematics}

Mathematics is foundational in many ways that informs our decisions in areas of our lives. Teaching and learning materials is at the heart of education life, provide skill acquisition, prepare students, for the workforce, and foster mathematical thinking (Ontario Ministry of Education, 2005). Mathematics involves learning to solve problem, investigate, represent and communicate mathematical concepts an ideas and making connections to everyday life (Ontaro Ministry of Education, 2005). Given the importance of mathematics, the following instructional strategies can help create effective classroom practices for supporting pupils' development in mathematic;

\section{Creating a Supportive and Engaging Classroom Environment}

A supportive ad engaging classroom environment is important to help develop pupils' mathematical e understanding and confidence. (Ontario ministry of Education, 2005). The classroom needs to be a place of investigation, where students do meaningful mathematics in a safe and positive space. "Meaningful mathematics takes place in classrooms that support pupils as they investigate, represent and connect mathematical ideas through discussion in the context of problem solving" (Suurtamm et al, 2005). Bruce (2007), who studied ways to improve pupils' educational experience in mathematics, explains that discussion in the mathematics classroom is very important. The mathematics classroom should feel like a community where ides can be discussed, developed, debated and understood (Bruce, 2007). One way to encourage classroom dialogue in mathematics is through "math talk". Math talk is a way to have structured mathematical discussion that constructs knowledge and meaning (Hufferd-Ackles, Fuson and Gamonan Sherin, 2004). Wagganer (2015), students become the co-constructors of knowledge through asking question, justifying their work and communicating their ideas to each other. Students are asked to explain their ideas, justify their thinking and question one another on their work and compare and contrast ideas and solutions (Suurtaamm et al., 2015).

\section{Provision of Strong Mathematics Foundation}

More and more jurisdictions, teachers' association and researchers (Duncan et al, 2007; Ontario ministry of education, 2003; national association for the education of young children (NAEYC) and national association of early childhood specialist in State Department of Education (NAECS/SDE 2003; national research council, 2009' students achievement division, 2011) continue to advocate for providing our very young children with a strong mathematics foundation. Providing our youngest learners with a strong mathematics foundation can play an important role in future academic achievement. Researchers have found that early year's mathematical skills can have a strong predictive power for future academic achievement (Duncan et al 2007). Moreover, the Canadian child care federation (2010) has found that most differences in children's monetary skills in school can be linked to the opportunities children has at home and early childhood environment.

\section{Develop Knowledge of Children's Developmental Process}

It is important for educators to be mindful of the developmental process and unique characteristics of young learners (students' achievement division, 2011). Young learners to through different stages of development as they grow and as a result, early years practitioners need to have a strong understanding of the development and characteristics of young learner (student achievement division, 2011).

\section{Being Knowledgeable About Mathematics}

Early childhood educators need to be knowledgeable about mathematics (student achievement division, 2011). A teacher we must be able to explain what we are doing and why in mathematics. Ball (2008) explains that teachers' content knowledge can play an important role in student achievement. NCTM (2013) suggests that early childhood educators attend professional development on mathematics content and teaching of math.

\section{Effective Teaching Strategies for Mathematics}

There is growing evidence that pupils develop procedural fluency in mathematics, but have difficulty with conceptual understanding (Lawson, 2007). Procedural fluency is the ability to apply and use steps or strategies for different problems (NCTM, n.d), while conceptual understanding is the knowledge of abstract ideas (Rittle-Johnson and Scheneider, 2014). Researchers stress the importance of teaching for conceptual understanding (Lawson, 2007, Protheroe, 2007). However, mathematics classes often focus on drills and 
procedural understanding (Protheroe, 2007), even though "the curriculum is designed to help students build the solid conceptual foundation in mathematics that will enable them to apply their knowledge and further their learning successfully". (Ontario ministry of Education, 2005 p.4). Memorizing mathematics is not sufficient for developing understanding. Students need to be taught to understand the concepts behind procedures (NCTM, nod). Hiebert (1999) explains that one pupil learn a produces, they often have little motivation to learn the underlying concepts behind the procedures and as such, the (NCTM (nd) recommends that pupils learn the concepts behind the instruction of procedures, not after.

The following are some additional recommended teaching practices for teaching conceptual understanding.

- When students are learning division, explain why they cannot divide by zero (Wathall, 2015).

- Students and pupils should be asked to justify their processes (NCTM, n.d) and give self-explanation (Tittle Johnson and Schenieder, 2014).

- Students should be pushed to work on interesting problems that allow for student generated solutions (Lawson, 2016) facilitate multiple presentation, and promote student interaction (Suutamm et al, 2015).

Problem-solving is a foundational building block for learning mathematics. "By learning to solve problems and by learning through problem-solving, pupils are given numerous opportunities to connect mathematics ideas and to develop conceptual understanding" (Ontario ministry of education, 2015, P.11). When the term problem-solving is used, it means that a solver is working on a question where the solver does not know a direct path to achieve the goal (Poolya 1945). Beigie (2008) "a mathematical question may be sophisticated, but it is not a problem unless the student makes real decision on how to construct the solution". As such, a problem exist when the method of solving is unknown and a solution is necessary (Dossey, McCrone and O'Sullivan, 2006). Suurtammn et al; (2015) who examined ways to make space for students to think mathematically, it is important to present problems in the mathematics classroom that are complex and rich, scaffolding and engagement without imposed procedural steps. Several researchers (Barwell, 2011, Hoffman and Bralier, 2008; Suurtamm et al., 2015) suggest having students solve open-ended problems. Open ended problems are question that allow for a variety of problems-solving method and a variety of answers. Suurtamm et al., (2015), open -ended improve sense -making because they are forced to work with unfamiliar situation without a guided solution method and procedure to follow.

Encourage and support students to collaborate in mathematics. Mathematics collaboration needs to be encouraged and supported in the classroom. Collaboration is an important way to foster mathematical understating and increased confidence in mathematics (MacMath, Wallace and XiaOhong, 2009. By providing a classroom environment where students feel comfortable to collaborate, share, explore and think mathematically, mathematical confidence can improve (Suurtamm et al, 2015). Substantial research exists explaining that collaboration improves self-confidence (Evans and Di, 1991), feelings of unity (Evans and Dion, 1991), improved satisfaction (Tett and Meyer, 1993) and cohesiveness (Evans and Dion, 1991). Collaborative work can lead to increased commitment and increased feeling of unity. Lewin (1943), the pioneer of group dynamics explains that, when people have a common goal, it is more likely to be achieved. During the world war II, Lewin researched this phenomenon, by testing whether people were more likely to eat undesirable food when they were in a group and indeed they were (Lewin, 1943). Similarly, promoting collaboration in the mathematics classroom may lead to increased commitment and unity (Suurtamm et al; 2015). Another benefit of collaboration is its effect on problem-solving. Small group brainstorming during the problem-solving process can have positive effects on later stages of the problem-solving process. Additionally -groups who brainstormed together benefit during the later steps of the problem-solving process due to increased coordination and cohesion when problem-solving (Fleming, 2000). Collaboration can also help with creating strong personal relationships. In the classroom environment, Hasler-Waters and Napier (2002) suggest that collaboration allows students to leverage the strength of their classroom, build relationships and learn team work.

In many mathematics classrooms, homework is assigned on a regular basis, but what does the research says about homework? According to the NCTM (n.d), homework can improve academic achievement, but the homework needs to be meaningful and purposeful. Swank (1999) studied whether drill based homework assignments improve achievement in math, and found no significant difference between students who 
completed the homework assignments and those who did not. As such, Swank (1999) argues that homework assignments should not be drill and practice tasks. Another important factor with homework is how to effectively take up homework. Otten, Cirillo and Herbel-Eisenman (2015) explain that often a large portion of class time is taken up with going over homework, one problem at a time, talking about correct answers or explanations. Otten et al., (2015) suggest instead of focusing on the mathematical ideas in the problems as a whole, similarities and differences between problems and actual students' approaches and thinking to the problems. Overall, the focus homework should be to improve conceptual understanding fluency and flexibility in math.

Making mathematics fun. Mathematics needs to be fun and engaging. According to Colgan (2014) a large majority of students find mathematics "boring, mostly irrelevant and unrewarding "(Colgan, 2014). This need not be the case, however as educators should strive to use resources and strategies that capture student interest and spike motivation (Colgan, 2014). Example includes use of:

- Educational app (such as kahoot 1)

- Math games (such as mathematic or the prime Radicals games (Colgan, 2014)

- TV programs /videos

- Use physical movements in the classroom to act the mathematics (Rittle-Johnson and Jordan, 2016). Building positive attitudes in mathematics. Having a positive outlook in mathematics is an important factor in student achievement (Colgan, 2014). Several researchers have found a positive correlation between positive mathematics attitudes and mathematics achievement, demonstrating that students with a positive attitude about mathematics had greater success in mathematics (Mata Monteriro and Peixoto, 2012). Several factors in the school environment including teacher support, student -tostudent interaction, and teacher expectations can affect attitude in mathematics (Mata et al; 2012). A key (2005) concluded that, students have a better attitude towards mathematics when their teacher has a very positive attitude about mathematics.

\section{The Concept of Place Value}

During the researcher time as a teacher the researcher noticed how some basic seven pupils of Samproso M/A JHS one struggle with place value concepts. Place value is an important number at basic seven. It is important because a secure knowledge of place value equips children to solve problems with number operation. Place value is the value of a digit in numerals.

Bigg and Button (1983) stated that the topic "place value" is the use of ten symbols in different positions to represent many values. Place value is one of the most difficult of the base number concepts for children to understand. For concepts, the number seventy -six (76), the value of the number symbol on the right hand side is 6 units and the number on the left hand side is $7 \times 10$ in 70 units.

Mishioo, (2007), the concept of place value is the ability to group objects into sets of equal size and then further collect together into sets of sets. He also said that, the position of a digit in a number gives a characteristics behavior different from the same digit in different numeral for instance, 7466 and 4667, the digit 4 in 7466 is 400 but in 4667 the digit is 4000 . This means that, the same digit " 4 " represent different value in 7466 and 4667 .

Asafo-Adjei (2006), children to be able to work with whole numbers greater than nine; they must understand the concept of place value. He defined place value as the position of a digit in a numeral. The concept of place value is applied when we follow the idea that the position of each digit in a numeral determines its value in the numeral. For instance, the position of the digits in the numeral 32754 is given as:

$\begin{array}{llllll}\text { Digits } & 3 & 2 & 7 & 5 & 4 \\ \text { Place value } & \text { tens of thousands } & \text { thousand } & \text { hundred } & \text { ten } & \text { ones }\end{array}$

It can be deduced that any number greater than nine has its value and value is different from the position of a digit in the numeral. Paling (1982) advocated the above explanation when he stated apparently that the value shown by a digit depends on its pace in a numeral. He cited an example as, the right hand 2 in 122 represent 20nes, but middle 2 represents 2 tens and 1 represents 1 hundred. Thus means that the children 
cannot comprehend the full algorithms of addition, subtraction, multiplication and division if they are not able to identify the value of a digit in a numeral.

Zaltan (1969) indicates that we use the place at which we write numbers to identify what kind of numbers we are thinking about. For instance, when we write 1453, that is one thousand, four hundred and fifty-three. What this means here is that we have one lot of thousand, four lots of hundreds, five lots of tens and three more object after that. The notion is that, a given numeral can be grouped into tens and ones. After that the rest of the tens will be grouped separately and the remaining will be countered as units or one. Thus 1453 will be 1 tens of ten of ten, 4 tens of ten 5 tens and 3 units. In order to scotch the misconception that mathematics is a difficult subject, teachers of the subject need to employ the use of concrete materials in teaching every concept of the discipline. Adjei (2001) is of the view that appropriate use of teaching and learning materials makes the teachers' lesson practical and real. He went on to say that teaching and learning materials save time because fewer words are used to explain a concept. The researchers agree on this statement because mathematics lesson one supposed to be taught practically so that pupils can derive solutions to the problem themselves. Asafo-Adjei (2002), again advocated the use of teaching and learning materials in teaching when he stated that teaching and learning materials make pupils active and increase pupils participation in lesson. The practicality of mathematics and other related subjects reflect when the needed teaching and learning materials are used. Obviously, a child needs a clear and full understanding of place value as an essential elements or tools in order to progress in addition, subtraction, multiplication and division. Young Loveridge (2001) notes that there are two broad concepts of numbers that are the basis of children understand when adding or subtracting multi-digit numbers. The place value ideas have been very essential in children's education. Many develop mentalist have proposed those ideas to be prudent at the early stages of the children's development in the concept of place value. It is obvious because, it deals with concrete materials and many experiences.

\section{Importance of Place Value}

- Each of the algorithms for whole numbers computation is based on place value ideas

- Children need to have a form comprehension of those ideas before they can work effectively with multiplication algorithms

- Linking idea directly with renaming ideas is a necessary steps as the algorithm for each operation is developed

- Providing numerous trading activities are accompanied by renaming activities.

\section{The Concept of Abacus}

Abacus is an ancient calculating device used primarily in Asian culture for performing arithmetic processes. Abacus device consist of a wooden or plastic frame with beads sliding on wires (Heffeifinger and Gray 2004). The word abacus dates before 138AD in Greek "abax" or "abacon" means table or tablet. In India, first century sources Abidharma Kosa, describes the knowledge and the use of abacus by Indian clerks. Even today abacus is used by Shopkeeper, merchants I Asia and China town in North America presently taught in Asia including India in preschool and elementary school as an aid in teaching arithmetic (Jakashi, www.akula.com). Memory is an act of an immense process of physiological activities at every act of memorization or information processing approach. The information processing approach divides memory into three general stages; sensory memory, short term memory, long term memory (Baddeley, 2011). Today in India, using abacus is an external agent extensively practiced to teach learners mathematics for children. Studies have shown that abacus not only mathematics calculation, but also develops memory consistently (Bhaskaran, Sengothlyan, Madhy, Ranganhtan, 2006). There may arise a question in one's mind that why is there a need to teach children to use abacus or to teach them solving arithmetical problems using abacus in this time of advanced technology. But the fact is that, even if the advancements are made in the technology making it possible for human beings to perform complex calculations and to explore new dimensions in the field of knowledge, the mind of the child is completely empty and it is to be written on. Childs mind could grapes something with difficulty and has the tendency of forgetting learnt topic after some time. (www. abacus lesson.com). With the help of abacus simple arithmetical functions are easy to learn especially multiplication which may see easier to an adult to perform but are very difficult for the juvenile to understand (www.abacuslesson.com). Sometimes it is needed to teach children how to use abacus. For 
instance, blind children are taught to use abacus because they cannot perform calculation on paper. Abacus has proved out to be an ideal too for those people as it allows them toc calculate easily and quickly while being reliable. The use of abacus is easy to understand for the new beginner and it also help in developing the mind of the children (www.abacuslessons.com).

\section{Importance of Abacus}

The abacus was invented by Charlse Babbage though it is now being used by the entire world to turn ion the mental abilities of young brains. Abacus training sharpens our memory and increases our ability to perform mental calculations. Abacus was designed in such a manner so that the brain visualizes the abacus while performing calculations which automatically activates the right part of our brain especially when we move our fingers over the beads and talk loud while solving the problem. However, one needs to enjoy the abacus education training process only the will one be able to truly benefit from the technique. The energy and abilities of our mind are not limited. It is the mater organ which takes all the decisions of the body. The left brain is also known as the digital brain whereas the right brain helps in creative pursuits. Both sides of our brain need to work in sync with each other and that is where abacus training helps us. Abacus training has become increasingly popular in India of late and helps the young minds understand the great number plan on which the universe is being run. Abacus calculation method helps in learning in number manipulation skills, decimal grasp and digit correlation among other skills. While electronic calculations need numbers as inputs, in abacus education, children learn to convert the beads into numbers and thus arrive at a result. The chain just goes on, the abacus sharpens the brains and the brain thus gains more expertise in solving mathematics problems using abacus.

In summary, it can be said that mathematics creates a supportive and engaging classroom environment, provision of strong mathematics foundation, being knowledgeable about mathematics and also place value means the value of a digit in numeral. A sound knowledge of place value helps pupils to perform the four basic operations in mathematics, thus addition, subtraction, multiplication and division.

\section{Research Design}

In the study, the action research design has been used. Action research according to Atiku (2005 unpublished) is a research which is conducted with the purpose of solving classroom or local school problems through the application of the scientific methods. It is concerned with finding immediate solutions for local problems encountered. Since it involves local problem, it is conducted in the local environment. Also, action research is undertaken to improve upon certain practices, Adzantu (2008). This is conducted by the practitioner with such pending issues or problems. This practitioner could be the teacher, supervisor or the headmaster or mistress. Johnson (2002), "The process of studying a real school or classroom situation in order to understand and improve the quality of actions or instructions. Johnson (2003), action research is also a type of inquiry that is preplanned, organized, and can be shared with others. Glanz (2003), "action research, as disciplined inquiry, is an invaluable tool that allows educational leaders to reflect upon their practices, programs and procedures." It seeks to document the context, change processes, resultant learning and theorizing of faculty in developing their pedagogies (Fisher and Phelps, 2006). John Elliott (1991) defines action research as: "Action research is the process through which teachers collaborate in evaluating their practices jointly; raise awareness of their personal theory; articulate a shared conception of values; try out new strategies to render the values expressed in their practice more consistent with educational value they espouse; record their work in a form which is readily available to and understandable by other teachers; and thus develop a stand theory of teaching by research practice". Action research is a process of systematic inquiry that enables people to find effective solutions to real problems encountered in daily life (Ferrance, 2000; Lewin, 1938; Stringer, 2007). Action research provides the means by which professional people may increase the effectiveness of the work in which they are engaged (Mills, 2013; Lingard et al., 2008; Stringer, 2008; Whitehead et al., 2003). Within the teaching profession, action research can be defined as the process of collaborative inquiry conducted by stakeholders to understand and improve the quality of actions on instruction (Hensen, 1996; McTaggart, 1997; Mills, 2013; Schmuck, 1997).

In light of this comment, Holter and Frabutt (2012) suggest that action research in education must be systematic, oriented toward positive change in the school community, practitioner - driven and participatory. Action research offers many benefits for educators committed to a critical, investigative process of improving school practice policy or culture. First, action research can be used to fill the gap between theory 
and practice (Johnson, 2012) and helps practitioners develop new knowledge directly related to their classroom (Hensen, 1996). Again, action research facilitates teacher empowerment (Fueyo and Koorland, 1997). Teachers are empowered when they are able to collect their own data to use in making decision about their schools and classroom (Book, 1996; Erickson, 1986; Hensen, 1996, Zeichner and Noffke, 2001). Moreover, when teachers are allowed to take risks and make changes related to teaching and learning, student achievement is enhanced (Marks and Louis 1997; Sweetland and Hoy, 2002), and schools become more effective learning communities (Detert, Louis and Schroeder, 2001). Furthermore, action research is an effective and worthwhile means of professional growth and development (Osterman and Kottkamp, 1993). Traditional teacher in-services are often ineffective (Barone et al., 1996) and generally do not give teachers sufficient time, activities, or content to increase their knowledge or affect their practice (Birman, Desimone, Porter and Garet, 2000). Teacher in-services on action research offer a way for teachers to reflect critically on their practice (Cain and Harris, 2013; Darling - Hammond and McLaughlin, 1995; Hodgson, 2013), stimulate change in their thinking and practice (Furlong and Salisbury 2005; Zeichner, 2003), and promote self-improvement and self-awareness (Judah and Richardson, 2006). Ultimately, the solutions-based focus, emphasis on fostering practitioner empowerment, and pragmatic appeal of action research collectively render this research methodology a worthwhile professional development activity for teachers (Hine, 2013).

In addition to the numerous benefits action research offers educators, there are several challenges associated with this research methodology. First, teachers and researchers may find that it is a time consuming process to conduct research in addition to the demands of their own instructional practice (Bailey, 1999; Hine, 2013, Wong, 1993). As such, these demands may impede the methodological rigor of data collection and critique (Waters - Adams, 2006).

As a corollary to the demands of the teaching profession, several authors cite the conflict between teaching and researching as detrimental to the quality of instruction given (Forster and Nixon, 1978; Wong, 1993). Again, action research is carried out by individuals who are interested parties in the research, the validity of collected and analyzed data may be questionably biased (Waters - Adams, 2006). Brown (2002), amplifies this comment by suggesting teachers and researchers may find it challenging to distance themselves from the situation being researched, and therefore, unable to attain an objective viewpoint. Lastly, another challenge faced by action researchers is to suspend any preconceived ideas of what the potential solution to the problem might be (Hine, 2013). In acknowledging a key tenet of action research, researchers must follow 'observe - reflect - act' process (Stringer, 2008). Therefore, assuming a course of action without enacting a rigorous methodology may be counterproductive to the research efforts overall. Instead, researchers must first speak to all project participants before arriving at a decision on how to proceed logically with a plan towards improvement.

\section{Population and Sample Selection}

This research was done in Samproso M/A JHS in Samproso town of Offinso South Municipal of Ashanti Region of the Republic of Ghana.

Table 1. The students population is tabulated below

\begin{tabular}{|l|l|l|}
\hline Sex & Number of Pupils & Percentage \\
\hline Boys & 78 & 52 \\
\hline Girls & 72 & 48 \\
\hline Total & $\mathbf{1 5 0}$ & $\mathbf{1 0 0}$ \\
\hline
\end{tabular}

From the table, a total of one-hundred and fifty (150) pupils constitute the entire population of the Junior High School (JHS) section. Out of this number seventy-eight (78) are boys and seventy-two (72) are girls. The main focus of this study was on Samproso M/A JHS one (1) class. There are sixty-five (65) pupils in the class. All the sixty-five (65) pupils were targeted population of the study because they share the same identified problem. Random sampling was used to select thirty-three (33) of the pupils as experimental group and the rest thirty-two as control group.

\section{Sample Technique}

Random sampling was done as follows: the alphabets ' $A$ ' and ' $B$ ' were written on pieces of paper and folded. The pupils were asked to pick one folded paper each. All those who picked ' $A$ ' formed the 
experimental group and those who picked 'B' formed the control group. The researchers choose random sampling technique because every pupil had the opportunity to be in either the experimental group or the control group.

\section{Research Instrument}

Since the purpose of the study was to come out with an improvised abacus to teach place value in JHS one (1), the researcher was moved to use range of methods for data collection. These were observation, interview test and questionnaire.

\section{Observation}

Observation, to Adzanku (2008), is the process of studying the outward and non-verbal behaviour of the person and recording what is observed as it happens. Observation helps researchers to identify problems associated with pupils' behaviour or other people. Through the researcher's observation, it was identified that J.H.S one (1) pupils of Samproso M/A JHS school find it difficult to participate in mathematics lessons. The researcher also observed that all classroom teachers in the school always use chalkboard illustration as the only teaching and learning materials (TLMs) neglecting the principle of multiple embodiment. This principle states that, mathematics concepts should be developed with several models, techniques, methods and skills, Mishiwo (2007). However, most teacher's fail to use teaching and learning materials (TLMs) during teaching and learning process. Based on researchers' observation, a clear conclusion can be drawn that, lack of teaching and learning materials (TLMs) in teaching process is the major cause of pupils' problems in mathematics.

\section{Interview}

Interview can be described as a face - to - face conversation between two people, Atiku (2005). The interview helped the researcher gather relevant information from pupils and even teachers. It also helped me to identify pupils' problems in the classroom as well as outside the classroom. As a way of collecting data, the researcher contacted his mentor with some questions which will help me ascertain information about the difficulty pupils encounter in understanding the concept of place value. From the conversation, it was evidently that teaching and learning materials (TLMs) required for teaching mathematics was not adequate. Pupils poor knowledge in mathematics could also be attributed to parents not buying books for their wards to be used at home. Pupils also attributed their inability to participate in mathematics to teachers not explaining the concept to them well. Someone also said that they will like to learn activity based subjects like Creative Arts and Physical Education. From the interview conducted, it came to light that lack of the use of teaching and learning materials (TLMs) at this basic level is promoting pupils difficulty in understanding also noted that pupils do not participate in mathematics lesson since the teaching and learning materials (TLMs) are not there to motivate learners. For this reason, pupils do not see mathematics as activity oriented subject.

\section{Test}

Test, to Delta (2007) is a set of questions, exercises or practical activities to measure someone's' skill, ability or knowledge. It is used to determine the weakness or strength of pupils in a lesson. Test is an instrument used to measure the level of ability of someone or somebody or a specific level of measurement. It may be administered orally or written depending on the purpose of which it was been set. The test items were designed to find pupils knowledge of understanding about the content of place value. It also helped the researcher to identify pupils problem and plan appropriate intervention for it. The items for the questions were carefully structured to the understanding of the pupils so that a valuable and valid response would be obtained for purpose of the study.

\section{Questionnaire}

Questionnaire was defined as a series of questions asked by individuals to obtain statistically useful information about a given topic. When questionnaire are properly constructed and responsibly administered, they become a vital instrument by which statement can be made about specific of people of entire population said in (wikipedia.org.). Francis Galton (2012) a questionnaire is a data collection instrument consistent of a series of questions and other prompts for the purpose of gathering information from respondents. Before a research constructs questionnaire for a group of people the researcher need to consider the following; how he will use the results of the questionnaire before he starts. The research objectives and frame of reference 
should be defined beforehand, including the questionnaire context of time. How (random or not) and from where (your sampling frame) he selects the respondents will determine whether you will be able to generalize his findings to the larger population. A sample is in appendix A.

\section{Pre-Intervention}

To confirm the facts gathered through observation and interview about lack of knowledge of pupils in place value, test items (questions) were given to pupils to responses were collect for analysis.

The table below shows pupils scores when the pre-test was conducted.

Table 1: Pre-Test Result

\begin{tabular}{|l|l|l|}
\hline Scores & Number of Pupils & Percentage (\%) \\
\hline $0-4$ & 53 & 81.54 \\
\hline $5-10$ & 12 & 18.46 \\
\hline Total & $\mathbf{6 5}$ & $\mathbf{1 0 0}$ \\
\hline
\end{tabular}

From the test conducted, the researcher realized that fifty-three pupils which constitute $81.54 \%$ had the marks below 5. Only twelve (12) pupils which constitute $18.46 \%$ scored the marks 5 and above which is the pass mark.

\section{Intervention}

Based upon the pupils' poor performance, the researcher embarked on this study to avert the situation. The intervention put in place by the researcher to help rectify the inability of JHS one (1) pupils of Samproso M/A Basic School to identify tens of thousands, thousands, hundred, tens and ones. An appropriate teaching and learning materials (abacus) was designed and used to teach the concept of place value. A detailed lesson plan was prepared to teach the concept of place value using abacus.

\section{Designing the Teaching and Learning Material}

Materials and tools needed for the teaching and learning material

\begin{tabular}{|l|l|}
\hline Tools & Materials \\
\hline Claw hammer & Hardwood \\
\hline Sand (Tenon and trip) & Nail \\
\hline Painting brush & Oil paint \\
\hline Sand paper (glass paper) & Iron rod \\
\hline Hacksaw & Beads \\
\hline & \\
\hline
\end{tabular}

\section{Construction of Abacus}

The abacus has the following parts;

Ones (units)

Tens

Thousands

Ten thousand

\section{The Abacus}

In constructing the abacus, a piece of hardwood measuring $40 \mathrm{~cm} \times 10 \mathrm{~cm} \times 2 \mathrm{~cm}$ was cut, planed and sand prepared. Five (5) holes were drilled along the length with equidistance from each other of $8 \mathrm{~cm}$. Rods of equal height were cut and fixed firmly into the five (5) drilled holes. The unit rod is the first rod at the right hand of the abacus followed by the tens, hundred, thousands and ten thousand rods. Below is the drawing of the abacus. 


\section{Post - Intervention}

After the intervention activities, similar graded test items (questions) were given to identify the place value of (4 - 5) digits in numerals. Pupils were able to identify ten thousand, thousand, hundred, tens and ones. Below (table 2) shows the pupils scores in the post - test conducted for the pupils.

Table 2: Post - Test Results

\begin{tabular}{|l|l|l|}
\hline Scores & Number of Pupils & Percentage (\%) \\
\hline $4-5$ & 10 & 15.38 \\
\hline $6-10$ & 55 & 84.62 \\
\hline Total & $\mathbf{6 5}$ & $\mathbf{1 0 0}$ \\
\hline
\end{tabular}

From the table above, the researcher realized that after the intervention, fifty-five (55) pupils which constitute $84.62 \%$ scored the marks of 5 - 10 and ten (10) pupils scored 0 - 4 which constitute $15.38 \%$. This shows that there is improvement in the understanding of mathematics when concrete teaching and learning material was used.

\section{Data Analysis}

The data collected after the intervention of the illustration of the simple tabular form and would be graphically represented in a bar chart. This would give the interpretation on how the results and findings were made from the administration of the test on the study. Moreover, they would bring out the numerical values, which are of greatest worth, that have been brought up from the study. Both the tables and chart would assist the researcher to understand what is involved in the data.

\section{Research Question 1}

What are the causes of place value difficulty among pupils?

Table 1: Teachers responses on the cause of place value difficulty among pupils.

\begin{tabular}{|l|c|c|}
\hline Items & No. of Respondents & Percentage (\%) \\
\hline Teaching and learning materials. & 2 & 7 \\
\hline Participation of pupils in class & 4 & 13 \\
\hline Teaching experience & 5 & 17 \\
\hline Methods used by teachers & 5 & 17 \\
\hline Periodic assignment / home work & 4 & 13 \\
\hline Organizing mental & 4 & 13 \\
\hline Mathematics period on the time table & 4 & 13 \\
\hline Teachers motivation & 2 & 7 \\
\hline Total & $\mathbf{3 0}$ & $\mathbf{1 0 0}$ \\
\hline
\end{tabular}

Source: Field Survey, 2019

From the table 1, two (2) out of thirty (30) teachers representing 7\% indicate that they lack teaching and learning materials to use in teaching place value. From educational perspective, the use of concrete and relevant teaching and learning aids makes pupils active and increase pupils' participation in the lesson. Supports Zoltan Dien (1978) developed a structural apparatus called 'Abacus' for learning algorithms. Zoltan is of the view that designing this apparatus was very essential because he believed that the everyday environment of the child does not sufficient situation of a type from which many mathematical concepts can be derived. This also support Piaget (1972), the child requires knowledge about objects and event in his own environment through activities. This implies that instructional procedures should provide to the learner and activity for him or her to know more about his or her environment. This also support Asafo-Adjei (2001) is of the view that appropriate use of teaching and learning materials make the teachers' lesson practical and 
real. Again, from the table, four (4) out of thirty (30) teachers representing $13 \%$ indicates that they lack the effort of given home work to pupils. From the perspective of educationist, given assignments and home works to pupils help the teacher to identify whether the pupils did understood his or her lessons. This support Swank (1999) studied whether drill based homework assignments improve achievement in math, and found no significant difference between students who completed the homework assignments and those who did not Otten, Cirillo and Herbel Eisenmann (2015) is of the view that, a large portion of class time is taken up with going over homework, one problem at a time, talking about correct answers or explanation. Otten et al., (2015) suggested that, instead of focusing on mathematical ideas in the problem as whole, similarities and differences between problems and actual student approaches and thinking to the problems. Overall, the focus of homework should be to improve understanding, fluency and flexibility in mathematics. Moreover, the table also showed five (5) out of thirty (30) representing 17\% which indicated that bad methods were used such as lecture method instead of activity method which will encourage the pupils to learn. This is supported by Asafo-Adjei (2002) advocated that the practicality and mathematics reflect when the need of teaching and learning materials used appropriate. Wagganer (2015), students become the coconstructors of knowledge through asking questions, justifying their work, and communicating their ideas to each other. Bruce (2007) suggests giving students sufficient time to do math talk, and not to intervene with probing questions or ideas too quickly.

Table 2 Pupils' response on the causes of the difficulty in place value.

\begin{tabular}{|l|l|l|}
\hline Items & No. Of Respondents & Percentage (\%) \\
\hline Lack of teaching and learning materials & 15 & 23 \\
\hline Bad method used by teachers & 12 & 18 \\
\hline Workload on pupils & 18 & 28 \\
\hline Lack of interest & 11 & 17 \\
\hline Inadequate time allocated & 9 & 14 \\
\hline Total & $\mathbf{6 5}$ & $\mathbf{1 0 0}$ \\
\hline
\end{tabular}

Source: Field Survey, 2019

From the Table 2, fifteen (15) out of sixty-five (65) pupils representing 23\% indicate that the school lacks effective teaching and learning aids pupil in this stage learn through pictures since all these materials are not in the school, it makes the lesson bored and ineffective. This is supported by Piaget (1972), the child requires knowledge about objects and even in his own environment through activities. Wales (2009) was of the opinion that the use of teaching and learning materials would make discovered facts flue firmly in the memory of learners. Savoury (2003), a well-planned use of teaching and learning materials in lessons should do much to banish apathy. In addition, he said that selection of teaching and learning materials which is related to the basic activity of a lesson helps in in-depth understanding of such a lesson by the learners, in that it makes the lesson attractive to them, thereby arresting their attention and thus motivating them to learn and participate.

Again, from the table 2, eleven (11) out of sixty-five (65) pupils representing $17 \%$ responded to lack of interest in mathematics which confirmed to what four (4) teachers responded in table 1 to be one of the causes of place value difficulty. Bruce (2007) found that although children from low income families performed more poorly in mathematics test, brain asymmetry had similar effects across income levels. The researcher found it that parents in low income families identified through participating in government subsidized school lunch program, spent significantly less time, helping their children with homework than the other parents children with both weak asymmetry and low income demonstrated the weakness mathematics mastery. Moreover, the researcher suggest that if teachers have enough time for these children, it can overcome that they do not have adequate time allocated on the school time table as discussed by the teachers in table 1 as a major cause of place value difficulty. This is supported by Richard (2014), students should be given an ample time to think, reasoning and to solve mathematical problems in order to yield pupils interest in the subject.

Table 3 Parents responds on pupils' difficulty in place value 


\begin{tabular}{|l|l|l|}
\hline Parents assistance to their wards & 2 & 10 \\
\hline Provision of textbook & 2 & 10 \\
\hline Pupils household chores & 13 & 65 \\
\hline Motivation & 3 & 15 \\
\hline Total & $\mathbf{2 0}$ & \\
\hline
\end{tabular}

Source: Field Survey, 2019

From the table 3, it can be indicated out of twenty (20) parents, only two (2) of them representing $10 \%$ assists the wards at home. This implies that majority of the parents do not have time for their wards homework, or assignments. They see it to be the duties of teachers only, which affect the child learning ability especially in mathematics as it is a day - to - day activities to be done. Again, two (2) out of twenty (20) representing $10 \%$ also responded that insufficient provision of textbook finds a lot of pupils ability to learn come from their parents. This is because some parents do not buy books for their wards; they see it as the duty of the government and the teachers. Parents need to buy a lot of mathematics textbook, mathematical set for their wards to improve their calculation skills. This is supported by Ray (1999), although calculators are really available to relieve the burden of computation, the ability to use algorithms is still considered superior. The National Council of Teachers of mathematics standards (1989) stress of the need for children to select and use computation technique appropriate to specific problem and determine whether the results are reasonable or not.

In addition, thirteen (13) out of twenty (20) parents representing 65\% also indicated that pupils' household chores have a great impact on pupils poor performance in place value. This means that majority of the pupils do not have time to go over what they were taught at school. They rather use all their time performing housework instead of learning.

\section{Research Question 2}

How possible will the use of abacus in teaching mathematics sustain the interest of the pupils of Samproso M/A JHS one (1)?

Table 4 Teachers responses to sustain pupils' interest in mathematics

\begin{tabular}{|l|l|l|}
\hline Items & No. of Respondents & Percentage (\%) \\
\hline Teachers self-motivation & 7 & 23 \\
\hline Method used by teachers & 6 & 20 \\
\hline Punctuality of teachers & 10 & 34 \\
\hline Exercise and homework & 7 & 23 \\
\hline Total & $\mathbf{3 0}$ & $\mathbf{1 0 0}$ \\
\hline
\end{tabular}

Source: Field Survey, 2019

From the table 4, seven (7) out of thirty teachers representing $23 \%$ indicate that they were self-motivated and enjoy teaching of place value using abacus in class. This supports Farrant (1980) suggests that a good activity in teaching should be characterized by the following features and purpose.

1. It should be enjoyable for those taking part of it.

2. It should sustain the interest of the pupils for as long as it takes them to succeed in whatever they are learning.

3. It should allow ample freedom for children to express themselves.

4. It should help the learner to get a better understanding about what is being learning.

The researchers also found that motivation improve teachers competences in teaching abacus. If someone is bored by learning abacus, he or she cannot understand the concept of place value in learning.

Moreover, seven (7) out of thirty (30) teachers representing $23 \%$ also responded that they do not have enough homework and assignment for their pupils. One importance of place value is that the more you solve questions on place value, the more you get in-depth knowledge of the concept. This Support Swank (1999) studied whether drill based homework or assignments improve achievement of mathematics goals. NCTN 
(n.d), homework can improve academic achievement, but the homework needs to be meaningful and purposeful.

Furthermore, ten (10) out of thirty (30) teachers representing $34 \%$ indicates that, if teachers are to be regular and punctual in school and as well as teaching the subject, it will help a lot of pupils to overcome their place value difficulties. This support Laplace (1989), in order to scotch the misconception that place value is a difficult subject teachers of the subject needs to employ the use of concrete materials and must be punctual to the subject.

Table 5: Pupils response on teaching of abacus to sustain their interest in mathematics lesson.

\begin{tabular}{|l|l|l|}
\hline Items & No. Of Respondents & Percentage (\%) \\
\hline Bad method used by teachers & 20 & 31 \\
\hline Inadequate time allocated & 5 & 8 \\
\hline Work load on pupils & 10 & 15 \\
\hline Teachers assistance to pupils & 15 & 23 \\
\hline Lack of teaching and learning materials & 15 & 23 \\
\hline Total & $\mathbf{6 5}$ & $\mathbf{1 0 0}$ \\
\hline
\end{tabular}

Source: Field Survey, 2019

From the table 5, twenty (20) out of sixty-five (65) pupils representing $31 \%$ responded that the method used by teachers is too poor. They used teacher centered only, instead of using (teacher-child method). Handbook on the teaching of place value at the JHS level suggest that it is very important to teach place value in Ghanaian schools, since there is a great concern about teaching. It also state that in order for teaching and learning to be effective, instruction should be built on pre-requisite skills. The researcher also said, if place value is taught using appropriate materials, pupils can solve place value questions without difficulty.

Again, five (5) out of sixty-five(65) pupils representing $8 \%$ indicate that inadequate time allocated on their time table leads to their difficulties in place value. This is supported by Richard (2014), students should be given ample time to think, reasoning and to solve mathematical problems in order yield pupils interest in the subject. In this case, pupils find it that mathematics on their time table everyday will help them to do better in place value questions.

Moreover, fifteen (15) out of sixty-five (65) pupils representing 23\% indicated that the use of teaching and learning materials must be effective in their mathematics lesson. Wales (2009) was of the opinion that the use of teaching and learning materials would make discovered facts glue firmly in the memory of learners. Savoury (2003), a well-planned use of teaching and learning materials in lesson should do much to banish apathy. In addition, he said that selection of teaching and learning materials which is related to the basic activities of a lesson helps in in-depth understanding of such a lesson by the learners, in that it makes the lesson attractive to them, thereby arresting their attention and thus motivating them to learn and participate.

\section{Research Question 3}

What are the roles parents play in education?

Table 6 Parent responds on the role parent play in education.

\begin{tabular}{|l|l|l|}
\hline Items & No. Of Respondents & Percentage (\%) \\
\hline Provision of textbook & 3 & 15 \\
\hline Motivation to pupils & 5 & 25 \\
\hline Pupils household chores & 4 & 20 \\
\hline Parent assistance to their ward & 8 & 40 \\
\hline Total & $\mathbf{2 0}$ & $\mathbf{1 0 0}$ \\
\hline
\end{tabular}

Source: Field Survey, 2019

From the table 6, it can be indicated out of twenty parents; only eight (8) assist their wards at home. This implies that majority of the parents do not have time for their ward homework, or assignment. They see it to be the duties of teachers only, which affect the child learning ability especially in mathematics as it is a day to - day activities to be done. Again, three (3) out of twenty (20) representing 15\% really affects pupils 
mathematics ability. The researcher finds a lot of pupils' ability to learn come from their parents. This is because, some parent does not buy textbooks for their wards, and they see it as the duty of the government and the teachers. Parents need to buy a lot of textbooks for their wards to improve their learning abilities. This is supported by Ray (1999), although calculators are really available to relive the burden of computation, the ability to use algorithms is still considered superior. The National Council of Teachers of Mathematics Standards (1989) stress of the need for children to select and use computation techniques appropriate to specific problem and determine whether the results are reasonable or not. In addition, four (4) out of twenty (20) parents representing $20 \%$ also indicated that pupils household chores have a great impact on pupils academic performance in place value. This means that majority of the pupils do not have time to go over what they were taught at school. They rather use all their time performing housework instead of learning.

\section{Results of the Pre-Test}

On the $6^{\text {th }}$ week of the term, during pre-intervention process, a test was conducted based on pupils ability on place value. The objective of this test was to know how pupils comprehend the place value concept at the end of the test. The results are tabulated below:

Table 7

\begin{tabular}{|l|c|}
\hline Name & Scores \\
\hline Lamhintey Comfort & 7 \\
\hline Animah Harriet & 3 \\
\hline Kwadwo Afriyie & 4 \\
\hline Thomas Akwasi & 0 \\
\hline Rahinatu Seidu & 2 \\
\hline Osman Yunus & 4 \\
\hline Ali Seidu & 3 \\
\hline Ali Yussif & 1 \\
\hline Iddrisu Rashida & 2 \\
\hline Adam Huraira & 5 \\
\hline Acheampong Christiana & 3 \\
\hline Oteng Samuel & 2 \\
\hline Amankwaa Francis & 1 \\
\hline Adwoa Afriyie & 2 \\
\hline Dauda Rashida & 4 \\
\hline Toffic Saliu & 3 \\
\hline Emmanuella Gyamfuaa & 2 \\
\hline Abdul Jabal Mohammed & 1 \\
\hline Adam Latifa & 1 \\
\hline Amdala Mumuni & 2 \\
\hline Addai Gladys & 2 \\
\hline Kwaku Francis & 3 \\
\hline Kwaku Kusi & 5 \\
\hline Teibatu Mumuni & 7 \\
\hline Owusu Gyan Premier & 6 \\
\hline Boadu Christiana & 2 \\
\hline Kwadwo Solomon & 0 \\
\hline Abeidatu Mumuni & 7 \\
\hline Takyiwaa Priscilla & 1 \\
\hline Awuni Priscilla & 5 \\
\hline Adu Gyamfi Emmanuella & 4 \\
\hline Gyamfi Gabriel & 6 \\
\hline Manu Micheal & 5 \\
\hline Antwiaa Faustina & 2 \\
\hline & \\
\hline
\end{tabular}




\begin{tabular}{|l|c|}
\hline Amadu Alijatu & 10 \\
\hline Amana Afamule & 0 \\
\hline Serwaa Christiana & 2 \\
\hline Naziru Seidu & 0 \\
\hline Muniru Seidu & 1 \\
\hline Hamza Mohammed & 7 \\
\hline Iddrisu Yussif & 3 \\
\hline Gyamfuaa Ophelia & 6 \\
\hline Boateng Elizabeth & 2 \\
\hline Iddisah Abdul Sharif & 6 \\
\hline Stephen Douda & 5 \\
\hline Diana Kuma & 3 \\
\hline Amankwaa Emmanuella & 2 \\
\hline Shuraju Iddrisu & 5 \\
\hline Gariba Nafisa & 4 \\
\hline Yakubu Aishatu & 2 \\
\hline Dorothy Offeh & 3 \\
\hline Abdul Hakim Mahama & 8 \\
\hline Antwi Boasiako & 4 \\
\hline Dzokoto Richmond & 9 \\
\hline Alhassan Yussif & 1 \\
\hline Aminatu Abubakari & 0 \\
\hline Abdul Rahman Yakubu & 2 \\
\hline Bavena Habib & 1 \\
\hline Adjei Kofi & 0 \\
\hline Siaka Adam & 2 \\
\hline Issah Sakina & 2 \\
\hline Theresa Nyarko & 1 \\
\hline El-ham Yahaya & 3 \\
\hline Owusu Bempah Prince & 0 \\
\hline Atta Samuel & 1 \\
\hline & \\
\hline & \\
\hline
\end{tabular}

Table 8: This table represents the frequency distribution on the pre-test scores.

\begin{tabular}{|c|c|c|c|}
\hline Marks & Tally & Frequency & Percentage (\%) \\
\hline $0-2$ & $\begin{array}{l}\text { HHH HH HHH HH } \\
\text { HH HH III }\end{array}$ & 33 & 51 \\
\hline $3-5$ & HIH HIH HIH HH & 20 & 31 \\
\hline $6-10$ & HIH HIH // & 12 & 18 \\
\hline Total & & 65 & 100 \\
\hline
\end{tabular}

Source: Field Survey, 2019

The test was marked out of ten. At the end of the test, the researcher observed that pupils were unable to score the test given. Below is a histogram showing the results of the pre-test. 


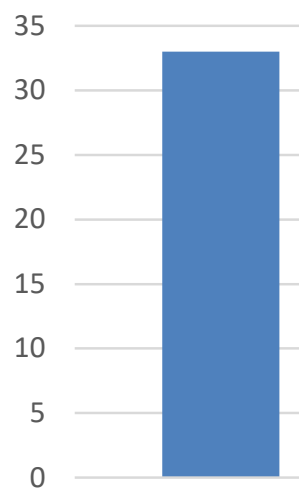

$0-2$

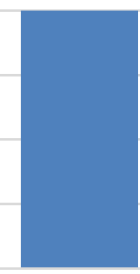

$3-5$

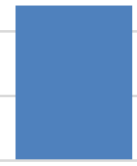

$6-10$ $\mathrm{x}$ - axis

- Marks

From the results in table 8, a total number of 65 pupils were used for the study, 33 pupils representing $51 \%$ scored from 0 - 2 marks, 20 pupils representing 31\% scored from 3 - 5 marks and 12 pupils representing $18 \%$ scored from 6 - 10 marks. In view of this, the researcher's objectives were mainly sought to solve problem in place value concept. Emphasis must be laid on the use of appropriate teaching and learning materials to improve on pupils place value concept. After using the appropriate teaching and learning material this abacus, this is the results that came out after the intervention.

Table 9 below is the results or marks obtained by the pupils on the post-test.

\begin{tabular}{|l|c|}
\hline Name & Scores \\
\hline Lamhintey Comfort & 9 \\
\hline Animah Harriet & 8 \\
\hline Kwadwo Afriyie & 7 \\
\hline Thomas Akwasi & 6 \\
\hline Rahinatu Seidu & 7 \\
\hline Osman Yunus & 3 \\
\hline Ali Seidu & 8 \\
\hline Ali Yussif & 4 \\
\hline Iddrisu Rashida & 10 \\
\hline Adam Huraira & 5 \\
\hline Acheampomaa Christiana & 2 \\
\hline Oteng Samuel & 5 \\
\hline Amankwaa Francis & 4 \\
\hline Adwoa Afriyie & 7 \\
\hline Dauda Rashida & 3 \\
\hline Toffic Saliu & 10 \\
\hline Emmanuella Gyamfuaa & 3 \\
\hline Abdul Jabal Mohammed & 7 \\
\hline Amdala Mumuni & 4 \\
\hline Adam Latifa & 8 \\
\hline Addai Gladys & 5 \\
\hline Kwaku Francis & 9 \\
\hline Kwaku Kusi & 10 \\
\hline Teibatu Mumuni & 10 \\
\hline Owusu Gyan Premier & 8 \\
\hline Boadu Christian & 1 \\
\hline Kwadwo Solomon & 10 \\
\hline Abeidatu Mumuni & \\
\hline
\end{tabular}




\begin{tabular}{|l|c|}
\hline Takyiwaa Priscilla & 3 \\
\hline Awuni Priscilla & 9 \\
\hline Adu Gyamfi Emmanuella & 9 \\
\hline Gyamfi Gabriel & 10 \\
\hline Manu Micheal & 10 \\
\hline Antwiwaa Faustina & 9 \\
\hline Amadu Alijatu & 10 \\
\hline Amana Afamule & 1 \\
\hline Serwaa Christiana & 2 \\
\hline Naziru Seidu & 2 \\
\hline Muniru Seidu & 1 \\
\hline Hamza Mohammed & 10 \\
\hline Iddrisu Yussif & 3 \\
\hline Gyamfuaa Ophelia & 10 \\
\hline Boateng Elizabeth & 8 \\
\hline Iddisah Abdul Sharif & 10 \\
\hline Stephen Duodu & 10 \\
\hline Diana Kumah & 9 \\
\hline Amankwaa Emmanuella & 7 \\
\hline Shuraju Iddrisu & 10 \\
\hline Gariba Nafisa & 6 \\
\hline Yakubu Aishatu & 2 \\
\hline Dorothy Offeh & 8 \\
\hline Abdul Hakim Mahama & 10 \\
\hline Antwi Boasiako & 10 \\
\hline Dzokoto Richmond & 10 \\
\hline Alhassan Yussif & 2 \\
\hline Aminatu Abubakar & 0 \\
\hline Abdul Rahman Yakubu & 3 \\
\hline Bauena Habib & 7 \\
\hline Adjei Kofi & 0 \\
\hline Siaka Adam & 0 \\
\hline Issah Sakina & 1 \\
\hline Theresa Nyarko & \\
\hline El-ham Yahaya & 7 \\
\hline Owusu Bempah Prince & 10 \\
\hline Atta Samuel & 1 \\
\hline & \\
\hline
\end{tabular}

Table 10: This table represents the frequency distribution on the post-test scores.

\begin{tabular}{|c|c|c|c|c|}
\hline Marks & Tally & Frequency & $\begin{array}{l}\text { Percentage } \\
(\%)\end{array}$ & $\begin{array}{l}\text { Angle } \\
\text { sector }\end{array}$ \\
\hline $0-2$ & HIH HIH III & 13 & 20 & 72 \\
\hline $3-5$ & $\mathrm{HH} \mathrm{HH} / \mathrm{H}$ & 12 & 18 & 66 \\
\hline $6-10$ & $\begin{array}{l}\text { HIH HWH HWH HWH } \\
\text { HH HWH HWH HHH }\end{array}$ & 40 & 62 & 222 \\
\hline Total & & 65 & 100 & 360 \\
\hline
\end{tabular}

Source: Field Survey, 2019

The test was marked out of ten. At the end of the test, the researcher observed that pupils were able to score the test items given. Below is a pie chart showing the results of the post-test.

A pie chart showing the results of the post-test 


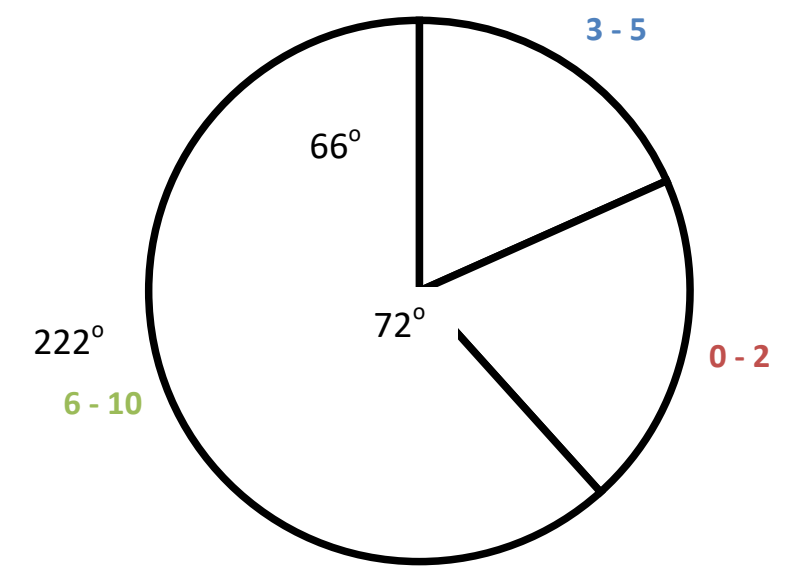

Source: Field Survey, 2019

The researchers' final objectives was sought to solve the problem of place value difficulties among pupils when strongly stressed on the use of abacus in teaching JHS one (1) pupils of Samproso M/A JHS basic school out of the intervention design and used by the teacher. This can also suggest that if teachers can use the appropriate teaching and learning materials proper and other desirable pedagogical approaches, this basic problem in mathematics can be minimized if not eliminated.

\section{Overview of the Study}

In recent times, some concerns have been expressed about poor performance of Samproso M/A JHS Basic School due to their poor performance in mathematics. This concern is very organizing given the relevance of mathematics in the learning processes. These concerns prompted the researcher to embark on the study to note out what is actually happening in the school with regards to teaching and learning of mathematics. The study sought to find out the causes of pupils difficulty in solving place value problem using abacus, and find ways of curbing the problem. The study also looked at the professional competencies of mathematics teachers and the availability and accessibility of teaching and learning materials (TLMs). The study used is the Action Design and Sample Random Sampling techniques. The population of the research consisted of thirty (30) teachers and sixty-five (65) pupils out of one hundred and fifty (150) pupils of the total population. The simple random sampling method was employed to select the pupils. Interview guide, questionnaire and observation were the instrument used to identify school-related cause of pupils' difficulty in understanding place value using abacus.

\section{Summary of Main Findings}

The study aimed at helping Samproso M/A JHS one (1) pupils to overcome their difficulty in solving place value using abacus. The following are the summary of the finding from the data collected and analyzed. The summary is done around the research questions which were centred on JHS (1) pupils difficulty in understanding place value using abacus.

\section{Research Question One}

What are the causes of place value difficulty among pupils?

The finding from this research is the academic and professional competencies which regularity and punctuality were included and this was confirmed by Lockhead and Koose (1999) that the amount of time available for teaching and how it was used by teachers and learners have direct bearing on students achievement and progress, another cause was the use of various techniques and methods in teaching and this was a major cause of poor performance of pupils place value using abacus. Another cause was the use of appropriate teaching and learning materials in teaching mathematics and it is known that most of the teachers do not use teaching aids in the teaching of mathematics which is causing poor performance in pupils. Teaching and learning materials are materials which are helpful to the teachers and students which maximize learning in various areas. 
Again, inability of teachers to understand and control emotions that were influencing the ability of students thus motivation of pupils with emotional problems often exhibit learning deficit because of their inability to integrate with other members of society and the child's ability to create meaningful relationship with other people and co-operate with others. Guraganus (2010) says that language problem is another problem of pupils in mathematics. Most pupils with mild disabilities have primary or secondary problem. Also, Ocadiz (2016) states that mathematics requires deductive reasoning and passive learners often struggle with this kind of problem solving. Students with memory and attention problems may struggle since both skills are necessary for mathematical aptitude. Other problem common to mathematics student include computational weaknesses, difficulty in conceptualizing mathematical principles and language challenges in word problem.

\section{Research Question Two}

How possible will the teaching of place value sustain the interest of pupils in mathematics lesson?

The findings from this research is that, among the competencies, very few teachers used the child-centered method as well as appropriate teaching and learning materials in delivering their lessons. Laplace (1989), in order to scotch the misconception that mathematics is a difficult subject, teachers of the subject need to employ the use of concrete materials and must make use of activity method of delivering mathematical lesson. This is because not all pupils are capable of digest the abstract things like numbers. It is therefore not advisable for a teacher to spend his energy with numbers when they cannot understand what he means. Before a teacher spends his energy and time with words, he should let manipulate materials and tools work for him, once they master the concept, he can start using numbers. Again, different strategies can be employed in the teaching of place value to basic level pupils. Olson (2016) also states that some of the approaches to sustain pupils' interest in place value is the use of concrete materials, such as abacus to yield pupils' understanding of the concept. The use of appropriate teaching methods, techniques and strategies facilitates the easy impartation of knowledge in learners, concretizes ideas and concepts for learners understanding, retention and memorization of place value concepts. It also makes the teachers use less time to deliver his lesson. The use of appropriate teaching and learning materials like using abacus imbues confident in pupils and help to eradicate the perception that place value is difficult in mathematics lesson.

\section{Research Question Three}

What are the roles parents play in education?

The findings from this research are that most of the parents at Samproso do not buy textbook for their wards. Parents' inability to cater for the needs of their wards contributed a huge deficit to the low performance of their wards. Parents play a key role in education, this is because parent are supposed to buy their wards their needs to help them study and to have a sound and concentrated mind to learn and in so doing it will improve their computation and learning strategies.

\section{Conclusion}

Most of the theories found in the literature review as stated by various renowned authors indicated that the concept of place value and the subject mathematics as a whole should be taught practically with teaching and learning materials since learners understanding is best enhanced by the use of teaching aids. Mathematics to pupils is difficult therefore teachers need to clear pupils' doubt that mathematics is not difficult. As seen in chapter three of the study, the researchers used the most appropriate teaching and learning material (abacus) to this effect and this brought the required improvement in the pupils' perception in mathematics lesson. It was also established that teachers vary their reinforcement schuedules.

\section{Recommendations}

(1) The following recommendations became necessary as a result of the analysis of data gathered. Appropriate and adequate teaching and learning materials should be supplied early by the Municipal Educational Directorate to enable teachers teach mathematics more effectively in order to make the understanding of mathematics concept more easier to pupils.

(2) Pupils should be taught how to study on their own since this will help them to broaden their knowledge in mathematics and other subject.

(3) Frequent calculation of mathematics problems will help pupils to keep rules and formulae at their fingers tips. 
(4) A concerted effort should be made by those who are involved in education to make sure that mathematics teachers go in for on the job training so as to keep them abreast of the increasing knowledge of mathematics and refresh and build the existing knowledge they have.

(5) Parents should also be made to ensure that their wards go school regularly and punctually so that the work of the teacher can move on smoothly.

(6) In teaching mathematics, it is always advisable to create a situation that will involve the use of multisensory approach. Finally, teachers should improve on their motivation skill in mathematics.

(7) Teachers should endeavour to improvise and use local materials to make the teaching and learning of mathematical concepts smooth and easy.

\section{Acknowledgements: Vida Kofour (Mrs.), Standly Antwi Boampong}

\section{References}

[1] Adjei, A. (2002), Teaching Basic School Mathematics for Colleges of Education. Kumasi learner's publishers.

[2] Asafo-Adjei. (2006). Teaching Basic School Mathematics for Colleges of Education. Kumasi learner's publishers.

[3] Adzanku, K. (2008). Assessment and Research in Basic School. Unpublished.)

[4] Beigie, D. (2008). Integrating content of create problem-solving opportunities. Mathematics Teaching in Middle School, 13(6), 352 - 360.

[5] Bruce, C.D. (2007). Student interaction in the math classroom: Stealing ideas or building understanding. Retrieved from

http://www.edu.gov.on.ca/eng/literacynumeracy/inspire/research/Bruce.pdf.

[6] Bruce, C.D. (2012). Technology in the mathematics classroom. What work? Research into practice: Secretariat. Retrieved from

[7] Burns, M. (1992). About teaching mathematics:Ak-12 resource. Cuisenaire Company of America.

[8] Colgan, L. (2014). Making math children will love: Building positive mathitude to improve student achievement in mathematics. What Works? Research into Practice Research Monograph 56. Student Achievement Division, Ontario Ministry of Education.

[9] EQAO (2011). Trends in International Mathematics and Science Study (TIMSS), 2011, Ontario Report.

[10] Gifford, S. (2015). Early years mathematics: How to create a nation of mathematics lovers? Retrieved from https://nrich.math.org/11441.

[11] Glanz, J. (2003). Action Research: An educational leader's guide to school improvement $\left(2^{\text {nd }}\right.$ edition). Norwood, MA: Christopher - Gordon Publishers, Inc.

[12] Hasler - Waters, L., and Napier, W. (2002). Building and supporting student team collaboration in the virtual classroom. Quarterly Review Distance Education, 3(3), 345 - 352.

[13] Hiebert, J. (1999). Relationships between research and the NCTM standards. Journals for Research in Mathematics Education, 30(1), 3 - 19.

[14] Hoffman, L.R., and Brahier, D.J. (2008). Improving the planning and teaching of mathematics by reflecting on research. Mathematics Teaching in the middle school, 13(7), 412 417.http://www.edu.gov.on.ca/eng/literacynumeracy/inspire/research/WW technology. pdf.

[15] Huffered - Ackles, K., Fuson, K.C. and Gamoran Sherin, M. (2004). Describing levels and components of a Math - Talk Learning Community. Journal for Research in Mathematics Education, 35(2): $81-116$.

[16] Johnson, A. (2003). What every teacher should know about action research. Boston, MA: Pearson Education, Inc.

[17] Lawson, A. (2007). Learning mathematics vs. Following 'Rules': The value of student - generated methods. What Works? Research into Practice. Student Achievement Division.

[18] Lawson, A. (2016). The mathematical territory between direct modelling and proficiency. What Works? Research into Practice. Student Achievement Division.

[19] Lewin, K. (1943). Bulletin of National Research Council. 
[20] Microsoft Encarta (2005).

[21] Mishiwo, M. (2007). Comprehensive Notes on Method of Teaching Basic School. Mathematics for Diploma Awarding Colleges. Unpublished.

[22] NAEYC (2003). Early Childhood Curriculum, assessment, and program evaluation: Building an effective, accountable system in program for mathematics.

[23] National Council of Teachers of Mathematics (2013). Why is mathematics important for early childhood learners? A Position of the National Council of Teachers of Mathematics.

[24] National Council of Teachers of Mathematics (n.d.). What does research say about the effectiveness of homework.

[25] National Council of Teachers of Mathematics (n.d.). What Procedural Fluency, and how do we help students develop it? A position of the National Council of Teachers of Mathematics.

[26] Ndzonyi, P. et al (2004). Foundation Mathematics for Ghana, Pupils Book 1 (JHS). Achimota, Accra:Wocli Publishing Service and Cosmos Publishers Ltd.

[27] Ontario Ministry of Education (2003). Early math strategy. The Report of the Expert Panel on Early Math in Ontario.

[28] Otten, S., Cirillo, M., and Herbal - Eisenmann, B.A. (2015). Making the most of going over homework. Mathematics Teaching in the Middle school, 21(2), 98 - 105.

[29] Paling, D. (1982). Teaching Mathematics in the Primary Schools. Oxford University Press.

[30] Piaget, J. (1972). The Growth of Logical thinking. London: Routledge and Kegan paul.

[31] Polya, G. (1945). How to solve it: A new aspect of mathematical method. Princeton, NJ: Princeton University Press.

[32] Protheroe, N. (2007). What does good math instruction look like? Principal, 87(1), 51 - 54.

[33] Richard Skemp (198). We teach them wrong. New York: Distributive Publishing Limited. Criterion Reference Test (CRT) (1992).

[34] Rittle - Johnson, B., and Schneider, M. (2014). Developing conceptual and procedural knowledge of mathematics. Oxford handbook of numerical cognition. Oxford, UK: Oxford University Press.

[35] Suurtamm, C., Quitgley B., and Lazarus, J. (2015). Making space for students to think mathematically. What Works? Research into practice.

[36] Swank, A.L.G. (1999). The effect of weekly math homework on students math performance.

[37] Wagganer, E.L. (2015). Creating math talk community. Teaching children mathematics, 22(4), 248 254.

[38] Zoltan, P.D. (1960). Building up mathematics. London: Hutchinson Educational. 